\title{
Insulin, S-sulphonate A and S-sulphonate B-Chain Receptor Binding to Human Cultured Lymphocytes
}

\author{
M. Kobayashi and J. C. Meek \\ Department of Internal Medicine, University of Kansas Medical Center, Kansas City, Kansas, USA
}

Summary. The ability of insulin and the S-sulphonate $\mathrm{A}$ and $\mathrm{B}$-chain derivatives to bind to a receptor on cultured human lymphocytes was evaluated. A receptor site for the S-sulphonate A-chain was identified and was strongly influenced by the intact insulin molecule. S-sulphonate A-chain weakly interfered with insulin binding. S-sulphonate B-chain showed no evidence of significant binding and did not interfere with insulin or S-sulphonate A chain binding. ${ }^{14} \mathrm{CO}_{2}$ production from ${ }^{14} \mathrm{C}$-1-glucose was stimulated by insulin in cultured lymphocytes and this effect was blunted by S-sulphonate A-chain. The sulphhydryl blocking agent used in the production of insulin A-chain appears to be of critical importance.

Key words: Insulin receptor, cultured lymphocytes, insulin structure function relationship, insulin chains.

Insulin receptors of cultured lymphocytes, circulating monocytes, fat cells, hepatocytes and muscle cells have been studied and characterized. The comparative binding affinity of insulin from various animals and insulin analogues, including proinsulin, generally show similarities in the characteristics of receptor binding and biologic activity [1-6].

It has previously been reported that the $A$ and B-chains of insulin do not bind to the insulin receptor $[1,7]$, although A-chain has been shown to have a biological effect upon adipose tissue [8-10] and isolated rat diaphragm [11]. We have investigated the binding affinity of S-sulphonate A and B-chain as well as the parent insulin molecule and have demonstrated that the S-sulphonate form of A-chain binds to cultured lymphocytes and is displaced by insulin. We have also demonstrated that insulin increases glucose uptake and $\mathrm{CO}_{2}$ production in cultured lymphocytes and this biologic effect is blunted by the addition of S-sulphonate A-chain.

\section{Materials and Method}

Bovine insulin (Sigma) was used for iodination, sulphitolysis and as unlabelled standard in the binding assays. Porcine proinsulin (\# 615-1112B-278) was a gift from Eli Lilly Company. Lactoperoxidase and carboxymethyl A-chain were purchased from Sigma and Calbiochem respectively. ${ }^{14} \mathrm{C}$-1-glucose (specific activity $50 \mu \mathrm{Ci} / \mathrm{mmole}$ ) was purchased from New England Nuclear. Human cultured lymphocytes, RPMI 1788, were used for all the binding assays and glucose oxidation assays.

\section{Preparation of $S$-sulphonate $A$ and $B$-Chain}

As previously described [8], bovine insulin was cleaved into the A and B-chains by sulphitolysis and separated by the method of Dixon and Wardlow [12]. The S-sulphonated $\left(\mathrm{SSO}_{3}\right)$ chains were tested for purity by cellulose acetate electrophoresis and these preparations were essentially purc, as previously described. Contamination with insulin was less than $0.005 \%$ by radioimmunoassay.

\section{Iodination of Insulin, S-sulphonate $A$ and B-Chain}

Insulin and its chains were iodinated both by use of Chloramin T [13] and lactoperoxidase methods [14]. Both methods were satisfactory and consistent and thereafter the lactoperoxidase method was used for the binding studies. Specific activity was $60-100$ 

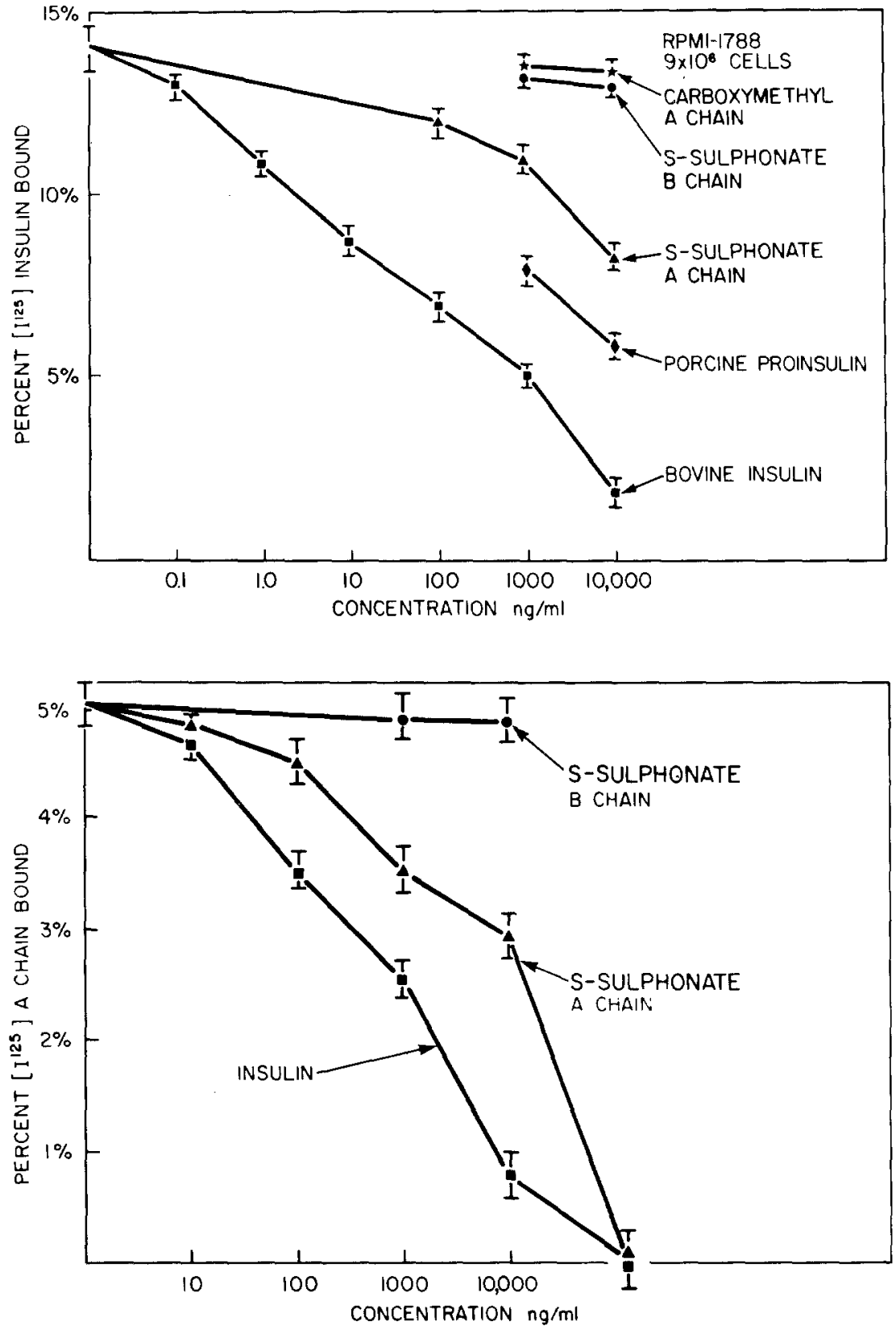

Fig. 1. Inhibiting effect of bovine insulin $(\mathbf{0})$, porcine proinsulin $(-\mathbf{-})$, S-sulphonate A-chain $(\boldsymbol{\Delta}-\mathbf{A})$, S-sulphonate B-chain (-) and carboxymethyl A-chain $\left(*{ }^{*}\right.$ ) ) on ${ }^{125}$ I-insulin binding to cultured lymphocytes (RPMI 1788) $\left(9 \times 10^{6} \mathrm{cells} / \mathrm{ml}\right)$. The data represents the mean of triplicate with S. D. and are corrected for nonspecific binding. The concentration of ${ }^{125} \mathrm{I}$-insulin was $1-2 \mathrm{ng} / \mathrm{ml}$. Nonspecific binding averaged $4.3 \%$. The proportion of nonspecific binding relative to total binding was $25 \%$
Fig. 2. Inhibiting effect of bovine insulin (1_- S-sulphonate A-chain $(\boldsymbol{\Delta}-\mathbf{A})$ and S-sulphonate B-chain (-) on ${ }^{125}$ I-S-sulphonate A-chain binding to cultured lymphocytes $\left(10 \times 10^{6}\right.$ cells $/ \mathrm{ml})$. The data represent the mean of triplicate with S. D. and are corrected for nonspecific binding. The concentration of ${ }^{125} \mathrm{I}$-S-sulphonate A-chain was $1-3 \mathrm{ng} / \mathrm{ml}$. Nonspccific binding averaged $3.1 \%$. The proportion of the nonspecific binding relative to total binding was $28 \%$ $\mu \mathrm{Ci} / \mu \mathrm{g}$ for insulin, $80-100 \mu \mathrm{Ci} / \mu \mathrm{g}$ for S-sulphonate $\mathrm{A}$ chain and B-chain.

\section{Binding Study}

Studies of ${ }^{125}$ I insulin binding to lymphocytes were conducted in plastic tubes containing 5-10 million cells $/ \mathrm{ml}$, labelled hormone and varying concentration of unlabelled hormone in Tris medium buffer, $\mathrm{pH} 7.4$ with $1 \% \mathrm{BSA}$ at room temperature for one hour. Separation of cells from media was done by Beckman microfuge centrifugation. The radioactivity was determined in both the cell pellet and total aliquot.
Assay ${ }^{14} \mathrm{CO}_{2}$ Production from ${ }^{14} \mathrm{C}-1-$-Glucose

Cultured human lymphocytes, RPMI 1788, 8-16 $\times$ $10^{6}$ cells were incubated with ${ }^{14} \mathrm{C}$ - 1 -glucose $(0.005$ $\mu \mathrm{Ci} / \mathrm{ml}$ ) and insulin, $\mathrm{A}$ and $\mathrm{B}$-chain in sealed Erlenmyer flasks, equipped with $\mathrm{CO}_{2}$ traps in the flask; incubation was terminated by $60 \%$ perchloric acid into the media. After another one hour, the radioactivity of hyamine was determined and lactate concentration in the supernatant was measured by the enzymatic method [15]. Each experiment was performed in triplicate. 


\section{Results}

\section{Studies of Insulin, S-sulphonate $A$ and B-Chain Binding}

Specific binding of ${ }^{125} \mathrm{I}$ insulin to the lymphocytes was $14 \%$ in the absence of unlabelled hormone and was displaced by insulin, proinsulin and S-sulphonate A-chain, but not by S-sulphonate B-chain or carboxymethyl A-chain (Fig. 1). Insulin was 120 times more potent on a molar basis than S-sulphonate $\mathrm{A}$-chain in the inhibition of ${ }^{125} \mathrm{I}$ insulin binding to lymphocytes. Specific binding of ${ }^{125}$ I S-sulphonate A-chain was $5 \%$ and was displaced ten times more effectively by insulin than S-sulphonate A-chain (Fig. 2). S-sulphonate B-chain did not produce significant displacement of ${ }^{125} \mathrm{I} \mathrm{S}$-sulphonate A-chain and ${ }^{125} \mathrm{I}$ S-sulphonate B-chain did not bind to lymphocytes specifically.

\section{Studies of ${ }^{14} \mathrm{CO}_{2}$ Production from ${ }^{14} \mathrm{C}-1$-Glucose}

Incubation of cultured lymphocytes with ${ }^{14} \mathrm{C}-1$-glucose showed a significant time dependent increase in ${ }^{14} \mathrm{CO}_{2}$ production, and was optimum at a physiological $\mathrm{pH}$ in contrast to an acid environment. The increment of ${ }^{14} \mathrm{CO}_{2}$ production from ${ }^{14} \mathrm{C}$-1-glucose correlated well with an increasing concentration of insulin $(\mathrm{r}=0.901)$, but more than $1 \mu \mathrm{g} / \mathrm{ml}$ of insulin was required to show a statistically significant increase of ${ }^{14} \mathrm{CO}_{2}$ production (Fig. 3). However, S-sulphonate $\mathrm{A}$ and $\mathrm{B}$-chain and carboxymethyl A-chain, at the concentration of $100 \mu \mathrm{g} / \mathrm{ml}$, did not affect ${ }^{14} \mathrm{CO}_{2}$ production. In order to explore the possibility of inhibition of insulin binding and biological effect by S-sulphonate A-chain, ${ }^{14} \mathrm{CO}_{2}$ production and lactic acid production were measured in the incubation media in which both insulin and S-sulphonate Achain were present. The effect of insulin at a concentration of $10 \mu \mathrm{g} / \mathrm{ml}$ was totally abolished by the presence of $100 \mu \mathrm{g} / \mathrm{ml}$ of S-sulphonate A-chain (Fig. 4).

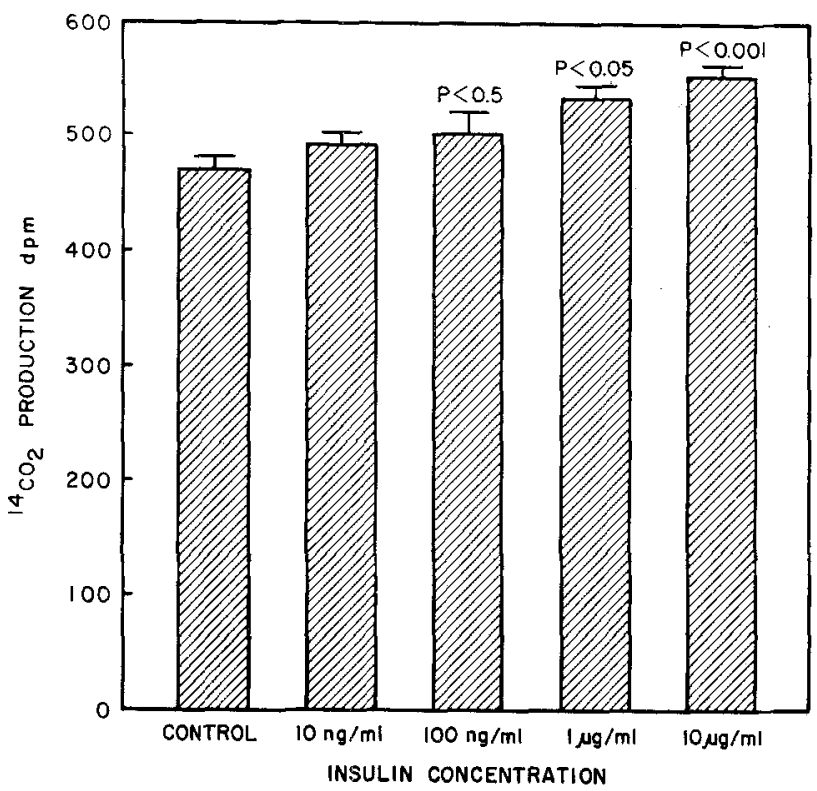

Fig. 3. ${ }^{14} \mathrm{CO}_{2}$ production from ${ }^{14} \mathrm{C}$-1-glucose by cultured lymphocytes $\left(10 \times 10^{6}\right.$ cells per flask) with various concentrations of insulin. The data represent the mean of triplicate estimation with S. D. All $P$ values were obtained by use of the paired $t$ test between control and the given insulin concentration. Correlation coefficient value ( $r$ ) for ${ }^{14} \mathrm{CO}_{2}$ production and the logarithm of insulin concentration from the raw data was 0.901

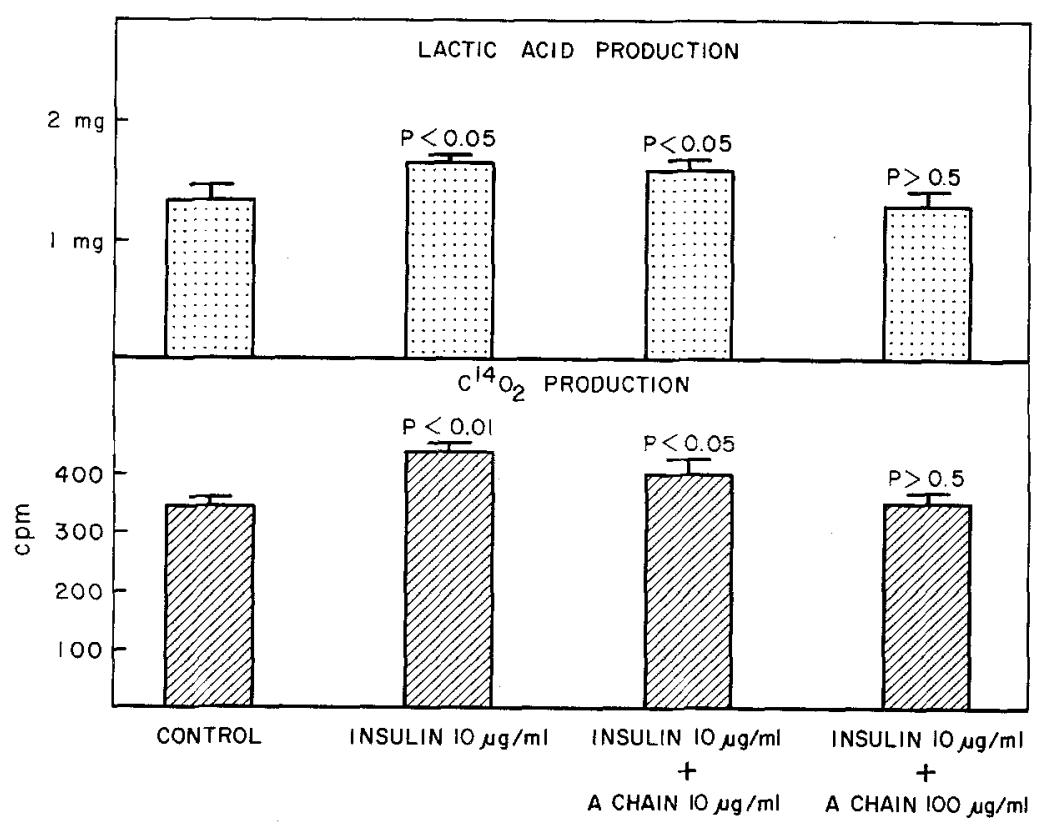

Fig. 4. ${ }^{14} \mathrm{CO}_{2}$ production from ${ }^{14} \mathrm{C}$-1-glucose by cultured lymphocytes $\left(8 \times 10^{6}\right.$ cells per flask) with insulin and S-sulphonate AChain. The data represent the mean of two separate experiments with S.D. Each experiment was done in triplicate. All $P$ values were obtained by use of the paired $t$ test between control and the given concentration of insulin and S-sulphonate A-chain 


\section{Discussion}

It is now generally accepted that the initial step in the biological action of insulin is binding of the molecule to specific protein receptors located on the surface of the cell membrane [4]. These receptors have been found in a variety of tissues including human isolated circulating mononuclear cells and cultured lymphocytes [7]. A number of current studies have attempted to relate insulin binding with biological activity. It has previously been suggested that the complete insulin molecule is necessary for the binding to occur, and this postulate was strengthened by the inability of the carboxymethyl form of insulin A-chain and B-chain effectively to displace labelled insulin from liver cell membranes [1], cultured lymphocytes [2] and human skin fibroblasts [2]. The data presented here, however, demonstrate that iodinated insulin is displaced from cultured lymphocytes by the S-sulphonate form of insulin A-chain. It appears that the sulphhydryl blocking agent used in the production of the Achain is of major importance since our work confirms the observation that the carboxymethyl Achain derivative is inactive in displacing the ${ }^{125} \mathrm{I}$ insulin. Since neither the S-sulphonate nor the carboxymethyl form of insulin B-chain interferes with insulin binding we assume that the A-chain portion of the insulin molecule is of primary importance in the binding affinity of insulin to its cell receptor. Although the S-sulphonate form of A-chain is only $0.8 \%$ as effective as the intact insulin molecule in displacing labelled insulin, this nevertheless is a significant degree of competition at the receptor site, which cannot be explained by contamination of Ssulphonate A-chain with native insulin. The degree of contamination of S-sulphonate A-chain by insulin as determined by radioimmunoassay was consistently less than $0.005 \%$ and was generally in the range of 0.005 to $0.001 \%$. This amount of contamination is similar to that observed in the development of specific antisera to insulin and the insulin chains [16] and is not sufficient to account for the observed changes by the S-sulphonate A-chain.

In addition to the ability of S-sulphonate Achain to interfere with insulin-receptor binding, this work suggests that there is a receptor on the cultured lymphocyte membrane capable of binding Ssulphonate A-chain directly. The degree of maximal binding of ${ }^{125} \mathrm{I}$ S-sulphonate $A$ chain at $5 \%$ suggests that the receptor site for A-chain is distinct from that of insulin. Nevertheless, the two receptors must be in close proximity since unlabelled intact insulin more readily displaces the labelled A-chain from the lymphocyte than does the unlabelled S-sulphonate
A-chain derivative itself. One cannot exclude the possibility that within the insulin receptor a particular region of the structure is competent to recognize the A-chain, although retaining higher affinity for native insulin. Again, since the carboxymethyl Achain derivative is ineffective in this system, it suggests that the blocking agent employed in the formation of the insulin derivatives is of great importance. This paper proposes that there is a close relationship between insulin A-chain and the intact molecule in regard to hormone-receptor function and should be considered in light of the current interest between insulin and other insulin-like proteins, such as NSILA, the somatomedins, and Concanavalin A [17, $18,19,20]$.

Although lymphocytes have not been generally regarded as a tissue that responds to insulin [21] some minor biological effects on lymphocytes have been described $[22,23]$. Because of the association of insulin binding to biological activity we attempted to demonstrate that ${ }^{14} \mathrm{CO}_{2}$ production from ${ }^{14} \mathrm{C}-1$ glucose and lactate production by lymphocytes could be enhanced by insulin. The large dose of insulin required, however, indicates that these cells are much less responsive than adipose or liver cells. Neither the S-sulphonate A-nor B-chain displayed an insulin-like action, as measured by ${ }^{14} \mathrm{CO}_{2}$ production. The S-sulphonate A-chain however, did inhibit both insulin-induced ${ }^{14} \mathrm{CO}_{2}$ production and lactate production. Freychet et al [5] and Gliemann and Gammeltoft [6] have previously demonstrated that the binding affinities of the insulin analogues to liver cell membranes and fat cells are closely related to their biological potency. Previously it has been reported that reduced A-chain (A-SH), either natural [8] or synthetic $[9,11]$, can produce an insulin-like biologic effect upon fat cells. In view of the ability of A-chain to influence insulin receptor binding and biological activity, it would be important to study Achain binding in adipose and liver cells. The present paper suggests that the A-chain binding studies should be extended to insulin receptors from other tissue and, in view of the recently described structure of NSILA, including two intrachain disulphide bridges [24], the correlation between insulin Achain and the group of proteins with nonsuppressible insulin-like activity should be evaluated.

\section{Literature}

1. Freychet, P., Roth, J., Neville, D., Jr.: Receptors in the liver: specific binding of $\mathbf{I}^{125}$ insulin to the plasma membrane and its relation to insulin bioactivity. Proc. Natl. Acad. Sci. USA 68, 1833-1837 (1971) 
2. Gavin, J. R. III, Gorden, P., Roth, J., Archer, J. A., Buell, D.: Characteristics of the human lymphocytes insulin receptor. J. Biol. Chem. 246, 2202-2207 (1973)

3. Kahn, C. R.: Membrane receptors for polypeptide hormones. Methods Membrane Biol. 3, 81-146 (1975)

4. Roth, J.: Peptide hormone binding to receptors: A review of direct studies in vitro. Metabolism 22, 1059-1073 (1973)

5. Freychet, P., Brandenburg, D., Wollmer, A.: Receptor-binding assay of chemically modified insulins. Diabetologia 10, $1-5(1974)$

6. Gliemann, J., Gammeltoft, S.: The biological activity and the binding affinity of modified insulins determined on isolated rat fat cells. Diabctologia 10, 105-113 (1974)

7. Gavin, J. R. III, Roth, J., Jen P., Freychet, P.: Insulin receptors in human circulating cells and fibroblasts. Proc. Natl. Acad. Sci. USA 69, 747-751 (1972)

8. Mcek, J.C., Bolinger, R. E.: The biological activity of insulin $\mathrm{A}$ and B-chains as determined by the rat diaphragm and epididymal fat pad. Biochemistry 5, 3198-3203 (1966)

9. Marglin, A., Cushman, S. W.: A biological activity of the A chain of insulin and the inactivity of A-synthetic analogue containing an intact interchain disulfied bridge. Biochem. Biophys. Res. Commun. 29, 710-716 (1967)

10. Marglin, A.: The synthesis of insulin by the solid phase method and the biological activities of synthetic and natural chains. In: J. Ostman, R. D. G. Milner (Eds.): Diabetes Proceedings of the Sixth Congress of International Diabetes Federation, Stockholm, Sweden, July 30-August 4, 1967, 395-399. Amsterdam: Excerpta Medica Foundation 1969

11. Volfin, P., Chambaut, A.M., Eoue-Bonis, D., Clauser, H., Brinkhoff, O., Bremer, H., Meienhofer, J., Zahn, H.: Biological activity of natural and synthetic insulin A-chain preparation on the isolated rat diaphragm. Naturc 203, 408-409 (1964)

12. Dixon, G.H., Wardlow, A. C.: Regeneration of insulin activity from the separated and inactive $A$ and $B$ chains. Nature 188, 721-724 (1960)

13. Freychet, P., Roth, J., Neville, D.M. Jr.: Monoiodoinsulin: demonstration of its biological activity and binding to fat cells and liver membranes. Biochem. Biophys. Res. Commun. 43, 400-408 (1971)

14. Thorell, J.I., Johansson, B.G.: Enzymatic iodination of polypeptides with $\mathrm{I}^{125}$ to high specific activity. Biochem. Biophys. Acta 251, 363-369 (1971)

15. Flcischer, W. R.: Enzymatic methods for lactic and pyruvic acids. In: R. P. McDonald (Ed.): Standard Methods in Clinical Chemistry 6, 245-259 (1970)
16. Meek, J. C., Doffing, K. M., Bolinger, R. E.: Radioimmunoassay of insulin $A$ and $B$ chains in normal and diabetic human plasma. Diabetes 17, 61-66 (1968)

17. Megyesi, K., Kahn, C.R., Roth, J., Gorden, P.: Hypoglycemia in association with extrapancreatic tumors: Demonstration of elevated plasma NSILA-s by a radioreceptor assay. J. Clin. Endocrinol. Metab. 38, 931-934 (1974)

18. Roth, J., Kahn, C.R., Lesniak, M. A., Gorden, P., DeMeyts, P., Megyesi, K., Neville, D. M.Jr., Gavin, J.R. III, Soll, A. H., Freychet, P., Goldfine, I. D., Bar, R.S., Archer, J.A.: Receptors for insulin, NSILA-s, and growth hormone: Application to disease states in man. Recent Prog. Horm. Res. 31, 95-140 (1975)

19. Van Wyk, J.J., Underwood, L.E., Hintz, R. L., Clemmons, D. R., Voina, S. J., Weaver, R. P.: The somatomedins: A family of insulin-like hormones under growth hormone control. Recent Prog. Horm. Res. 30, 259-318 (1974)

20. Cuatrecasas, P.: Interaction of Concanavalin A and wheat germ agglutinin with the insulin receptor of fat cells and liver. J. Biol. Chem. 248, 3528-3534 (1973)

21. Narahara, H.T., Cori, C. F.: Hormonal control of carbohydrate metabolism in muscle. In: F. Dickens, B. J. Randle, J. Whelan (Eds.): Carbohydrate metabolism and its disorders, 375-395. New York: Academic Press 1968

22. Boyett, J.D., Hofert, J.F.: Stimulatory effect of insulin on glucose metabolism of thymus lymphocytes. Horm. Metab. Res. 4, 163-167 (1972)

23. Hadden, J. W., Hadden, E. M., Wilson, E. E., Good, R. A., Coffey, R.G.: Direct action of insulin on plasma membrane ATPase activity in human lymphocytes. Nature [New Biol.] 35, 174-177 (1972)

24. Rinderknecht, E., Humbel, R. E.: Polypeptides with nonsuppressible insulin-like and cell-growth promoting activities in human serum: Isolation, chemical characterization and some biological properties of forms I and II. Proc. Natl. Acad. Sci. USA 73, 2365-2369 (1976)

Received: April 5, 1976, and in revised form: February 2, 1977

J. C. Mcek, Jr., M.D.

The University of Kansas Medical Center

College of Health Science and Hospital

Rainbow Boulevard at 39 th

Kansas City, KS 66103

USA 